\title{
Efficacy of PD-1 or PD-L1 inhibitors and PD-L1 expression status in cancer: meta-analysis
}

\author{
Xian Shen, Bin Zhao
}

Center for Precision Medicine, 109 Xueyuan West Road, the Second Affiliated Hospital and Yuying Children's Hospital of Wenzhou Medical University, Wenzhou, 325027, China

Correspondence to: B Zhao doctorbinzhao@126.com

Additional material is published online only. To view please visit the journal online.

Cite this as: $B M J$ 2018;362:k3529 http://dx.doi.org/10.1136/bmj.k3529 Accepted: 25 July 2018

\author{
ABSTRACT \\ OBJECTIVE \\ To evaluate the relative efficacy of programmed cell \\ death 1 (PD-1) or programmed cell death ligand 1 \\ (PD-L1) inhibitors versus conventional drugs in \\ patients with cancer that were PD-L1 positive and \\ PD-L1 negative. \\ DESIGN \\ Meta-analysis of randomised controlled trials. \\ DATA SOURCES
}

PubMed, Embase, Cochrane database, and conference abstracts presented at the American Society of Clinical Oncology and European Society of Medical Oncology up to March 2018.

REVIEW METHODS

Studies of PD-1 or PD-L1 inhibitors (avelumab, atezolizumab, durvalumab, nivolumab, and pembrolizumab) that had available hazard ratios for death based on PD-L1 positivity or negativity were included. The threshold for PD-L1 positivity or negativity was that PD-L1 stained cell accounted for $1 \%$ of tumour cells, or tumour and immune cells, assayed by immunohistochemistry staining methods.

RESULTS

4174 patients with advanced or metastatic cancers from eight randomised controlled trials were included in this study. Compared with conventional agents, PD-1 or PD-L1 inhibitors were associated with significantly prolonged overall survival in both patients that were PD-L1 positive $(n=2254$, hazard ratio $0.66,95 \%$ confidence interval 0.59 to 0.74 ) and PD-L1 negative (1920, 0.80, 0.71 to 0.90). However, the efficacies of PD-1 or PD-L1 blockade treatment in patients that were PD-L1 positive and PD-L1 negative were significantly different ( $\mathrm{P}=0.02$ for interaction). Additionally, in both patients that were PD-L1 positive and PD-L1 negative, the long term clinical benefits from PD-1 or PD-L1 blockade were observed

\section{WHAT IS ALREADY KNOWN ON THIS TOPIC}

Programmed cell death 1 (PD-1) and programmed death-ligand 1 (PD-L1)

inhibitors are effective at treating several cancers

Direct evaluation of the PD-L1 expression is treated as biologically plausible and the best available biomarker in predicting the tumour response and survival prognosis

The literature shows that patients that are PD-L1 negative benefit from PD-1 or PD-L1 blockade therapy

\section{WHAT THIS STUDY ADDS}

PD-1 or PD-L1 blockade therapy is preferable to conventional therapy for treating patients with advanced solid tumours that are PD-L1 positive and PD-L1 negative PD-L1 expression status alone is insufficient in determining which patients should be offered PD-10r PD-L1 blockade therapy consistently across interventional agent, cancer histotype, method of randomisation stratification, type of immunohistochemical scoring system, drug target, type of control group, and median follow-up time.

\section{CONCLUSIONS}

PD-1 or PD-L1 blockade therapy is a preferable treatment option over conventional therapy for both patients that are PD-L1 positive and PD-L1 negative. This finding suggests that PD-L1 expression status alone is insufficient in determining which patients should be offered PD-1 or PD-L1 blockade therapy.

\section{Introduction}

The immune suppression and evasion of malignant cancer cells is known as one of the hallmarks of cancer. ${ }^{1}$ A series of co-inhibitory and co-stimulatory receptors and their ligands, known as immune checkpoints, control this process. Among them, programmed cell death 1 (PD-1) and programmed cell death ligand 1 (PD-L1) axis stands out as a valuable therapeutic target because it not only plays a key role in physiological immune homoeostasis, but also appears to be a means through which cancer cells evade the immune system. ${ }^{2}$ The development and application of antibodies targeting PD-1 (nivolumab and pembrolizumab) and PD-L1 (atezolizumab, avelumab, and durvalumab) have advanced the treatment of cancer. ${ }^{3}$ Currently, PD-1 or PD-L1 inhibitors are being investigated in more than 1000 clinical trials and are licensed to treat a variety of cancers. ${ }^{23}$

The introduction of PD-1 or PD-L1 inhibitors into clinical practice has had a revolutionary effect on cancer treatment, but consistent responses and favourable long-term outcomes are only observed in a fraction of patients. ${ }^{4}$ Moreover, immunotherapy is associated with several immune-related adverse events, ${ }^{5}$ and has an estimated cost of more than $£ 234000$ (€258000; \$300000) per quality adjusted life year. ${ }^{6}$ Accordingly, identifying the optimal biomarkers that can predict the benefit of PD-1 or PD-L1 inhibitors is important in selecting the appropriate subjects for immunotherapies. Currently, direct evaluation of PDL1 expression is treated as biologically plausible and the best available biomarker in predicting the tumour response and survival prognosis. ${ }^{7}$ Numerous studies have consistently shown longer overall survival and better tolerability of PD-1 or PD-L1 inhibitors compared with conventional therapy in patients that are PD-L1 positive. ${ }^{8-16}$ Considering the fundamental nature of these checkpoint inhibitors, it seems logical that PD-L1 expression should be correlated with clinical outcomes. However, a non-negligible number of exceptions are observed in clinical practice. Tumour 
responses have been reported in $0 \%$ to $17 \%$ of patients with low or undetectable PD-L1 expression. ${ }^{17}$ In some trials, ${ }^{81018}$ even favourable long-term outcomes can be achieved in patients that are PD-L1 negative. Accordingly, the predictive and prognostic roles of PD-L1 status remain undetermined. In fact, PD-L1 expression status has not been approved in patient selection, although complementary PD-L1 test methods have been accepted by United States Food and Drug Administration. ${ }^{19}$

Currently, no studies explore the association between the efficacy of PD-1 or PD-L1 inhibitors and PD-L1 expression status. A pooled analysis of available trials restricted to patients that were PD-L1 positive and PD-L1 negative may provide critical and clinically useful information with respect to anti-PD-1 or antiPD-L1 treatment. Here, with recently accumulated evidence, we conduct a meta-analysis to evaluate the relative efficacy of PD-1 or PD-L1 inhibitors in both patients with cancer that were PD-L1 positive and PDL1 negative.

\section{Methods}

This study was conducted in compliance with the recommendations of the Cochrane Handbook for Systematic Reviews of Interventions and reported based on the Preferred Reporting Items for Systematic Reviews and Meta-Analyses (PRISMA) statement guidelines. ${ }^{20}$

\section{Literature search and study selection}

We conducted a comprehensive systematic search of PubMed, Embase, and Cochrane databases from inception to March 2018 with no language restrictions. Given that recent studies might be unpublished, additional electronic searches were performed through two major international congresses' proceedings (American Society of Clinical Oncology Annual Meeting and European Society of Medical Oncology). The main keywords used were: avelumab, atezolizumab, durvalumab, pembrolizumab, nivolumab, checkpoint inhibitors, PD-1, PD-L1, and randomised controlled trial (see supplementary materials, search strategies).

Both exclusion and inclusion criteria were prespecified. To be eligible, randomised controlled trials had to meet several criteria. Firstly, population: the PD-L1 status of the included patients (aged >18) were examined. The threshold for PD-L1 positivity or negativity was that PD-L1 stained cells accounted for $1 \%$ of tumour cells, or tumour and immune cells, assayed by immunohistochemistry staining methods. Secondly, intervention: treated with PD-1 or PD-L1 inhibitors (avelumab, atezolizumab, durvalumab, pembrolizumab, and nivolumab) irrespective of dosage and duration. Thirdly, main outcome: the primary outcome was overall survival measured as hazard ratios according to the positivity or negativity of PD-L1 expression.

Studies were excluded if they were retrospective or prospective observational cohort studies. In addition, phase I and non-randomised phase II studies were excluded. Other publications on the topic were also removed if they were review articles, basic science papers, commentaries, conference abstracts, quality of life studies, editorials, cost effectiveness analyses, early versions of data later published, and articles in which the effect of the drug could not be ascertained (eg, when the control was a different dose of the same drug). Moreover, the reference lists of all trials fulfilling the eligibility criteria were also examined for any relevant studies missed by initial searches. When the same clinical trial appeared in multiple articles, or cases were mixed between different publications, the most recent, or most complete reporting study, or both, were included. Discrepancies were settled by discussion and consensus. All the included trials represented unique studies.

\begin{tabular}{|c|c|c|c|c|c|c|c|c|c|c|c|c|c|}
\hline \multirow[b]{3}{*}{ Study } & \multirow[b]{3}{*}{$\begin{array}{l}\text { Trial } \\
\text { phase }\end{array}$} & \multirow[b]{3}{*}{$\begin{array}{l}\text { Line of } \\
\text { treatment }\end{array}$} & \multirow[b]{3}{*}{$\begin{array}{l}\text { Underlying } \\
\text { malignancy }\end{array}$} & \multirow[b]{3}{*}{$\begin{array}{l}\text { Experimental } \\
\text { drugs }\end{array}$} & \multirow{3}{*}{$\begin{array}{l}\text { PD-L1 } \\
\text { antibody } \\
\text { clone }\end{array}$} & \multirow[b]{3}{*}{$\begin{array}{l}\text { Assay } \\
\text { developer }\end{array}$} & \multirow{3}{*}{$\begin{array}{l}\text { IHC } \\
\text { scoring } \\
\text { method }\end{array}$} & \multirow{3}{*}{$\begin{array}{l}\text { Randomisation } \\
\text { stratified by } \\
\text { PD-L1 } \\
\text { expression }\end{array}$} & \multicolumn{4}{|c|}{ No of patients } & \multirow{3}{*}{$\begin{array}{l}\text { Median } \\
\text { follow-up } \\
\text { (months) }\end{array}$} \\
\hline & & & & & & & & & \multicolumn{2}{|c|}{ Intervention } & \multicolumn{2}{|l|}{ Control } & \\
\hline & & & & & & & & & $\begin{array}{l}\text { PD-L1 } \\
\text { negative }\end{array}$ & $\begin{array}{l}\text { PD-1 } \\
\text { positive }\end{array}$ & $\begin{array}{l}\text { PD-L1 } \\
\text { negative }\end{array}$ & $\begin{array}{l}\text { PD-1 } \\
\text { positive }\end{array}$ & \\
\hline $\begin{array}{l}\text { CheckMate } \\
017^{89}\end{array}$ & III & 2nd & Lung cancer & $\begin{array}{l}\text { Nivolumab } v \\
\text { docetaxel }\end{array}$ & $28-8$ & Dako & Type I & No & 54 & 63 & 52 & 56 & $>24$ \\
\hline $\begin{array}{l}\text { CheckMate } \\
025^{10}\end{array}$ & III & 2nd or later & $\begin{array}{l}\text { Renal } \\
\text { cancer }\end{array}$ & $\begin{array}{l}\text { Nivolumab } v \\
\text { everolimus }\end{array}$ & NR & Dako & Type I & No & 276 & 94 & 299 & 87 & 14 \\
\hline $\begin{array}{l}\text { CheckMate } \\
057^{811}\end{array}$ & III & 2nd or later & Lung cancer & $\begin{array}{l}\text { Nivolumab } v \\
\text { docetaxel }\end{array}$ & $28-8$ & Dako & Type I & No & 108 & 123 & 101 & 123 & $>24$ \\
\hline $\begin{array}{l}\text { CheckMate } \\
141^{12}\end{array}$ & III & 2nd or later & $\begin{array}{l}\text { Head and } \\
\text { neck cancer }\end{array}$ & $\begin{array}{l}\text { Nivolumab } v \\
\text { chemotherapy }\end{array}$ & $28-8$ & Dako & Type I & No & 73 & 88 & 38 & 61 & 5.1 \\
\hline KEYNOTE-006 ${ }^{13}$ & III & 1st or 2 nd & Melanoma & $\begin{array}{l}\text { Pembrolizumab } \\
v \text { ipilimumab }\end{array}$ & $22 C 3$ & Merck & Type II & Yes & 103 & 446 & 47 & 225 & 22.9 \\
\hline KEYNOTE-045 ${ }^{14}$ & III & 2nd or later & $\begin{array}{l}\text { Urothelial } \\
\text { cancer }\end{array}$ & $\begin{array}{l}\text { Pembrolizumab } \\
v \text { chemotherapy }\end{array}$ & $22 C 3$ & Dako & Type II & No & $N R^{*}$ & NRt & $N R^{\star}$ & NRt & 14.1 \\
\hline OAK $^{15}$ & III & 2nd or later & Lung cancer & $\begin{array}{l}\text { Atezolizumab } v \\
\text { docetaxel }\end{array}$ & SP142 & VENTANA & Type II & Yes & 180 & 241 & 199 & 222 & 21 \\
\hline POPLAR $^{16}$ & II & 2nd or later & Lung cancer & $\begin{array}{l}\text { Atezolizumab v } \\
\text { docetaxel }\end{array}$ & SP142 & VENTANA & Type II & Yes & 51 & 93 & 41 & 102 & 14.8 \\
\hline
\end{tabular}




\section{Data extraction and risk of bias assessment}

The key exposure variable was the intervention of PD-1 or PD-L1 inhibitors. In six trials, conventional chemotherapy served as the control. In two studies, namely KEYNOTE-006 and CheckMate 025, ${ }^{10}{ }^{13}$ ipilimumab and everolimus served as the control drugs. Randomised treatment allocation sequences were generated in all studies, however, randomisation stratified by PD-L1 expression was only conducted in KEYNOTE-006, ${ }^{13}$ OAK, ${ }^{15}$ and POPLAR. ${ }^{16}$

Data extraction was carried out using a standardised data collection form. We extracted the reported hazard ratios for overall survival from eligible trials. The following clinicopathological characteristics for each study were recorded: the name of study, trial phase, line of treatment, underlying malignancy, PD-1 or PD-L1 inhibitors, the antibody clones, assay developers for PD-L1 detection, randomisation stratified by PD-L1 expression, number of patients who were PD-L1 negative or positive, median follow-up time, and hazard ratio for overall survival according to the positivity or negativity of PD-L1 (see table 1). We also extracted the inclusion or exclusion criteria for patient selection, previous treatments administrated, the experimental treatment regimen, and the total number of patients recruited in each study (see table 2).

The Cochrane Risk of Bias Tool was applied to evaluate the risk of bias. ${ }^{21}$ We examined every trial and scored it as high, low, or unclear risk of bias to the following criteria: random sequence generation; allocation concealment; blinding of participants and personnel to the study protocol; blinding of outcome assessment;

\begin{tabular}{|c|c|c|c|c|c|}
\hline Study & Inclusion criteria for patient selection & Exclusion criteria for patient selection & Previous treatment & Treatment & No of patients* \\
\hline CheckMate $017^{89}$ & $\begin{array}{l}\text { Previously treated stage IIIB or IV } \\
\text { Squamous-cell NSCLC; aged }>18 ; \mathrm{ECOG} \\
\mathrm{PS}=0 \text { or } 1 .\end{array}$ & $\begin{array}{l}\text { Autoimmune disease, symptomatic } \\
\text { interstitial lung disease; systemic immu- } \\
\text { nosuppression; prior therapy with T cell } \\
\text { costimulation or checkpoint-targeted } \\
\text { agents; prior docetaxel therapy; more than } \\
\text { one prior systemic therapy. }\end{array}$ & $\begin{array}{l}\text { One prior platinum- } \\
\text { containing regimen }\end{array}$ & $\begin{array}{l}\text { Nivolumab }(3 \mathrm{mg} / \\
\mathrm{kg} \text { every } 2 \text { weeks) or } \\
\text { docetaxel }\left(75 \mathrm{mg} / \mathrm{m}^{2}\right. \\
\text { every } 3 \text { weeks })\end{array}$ & $272(135 / 137)$ \\
\hline CheckMate $025^{10}$ & $\begin{array}{l}\text { Previously treated advanced or metastatic } \\
\text { renal-cell carcinoma; less than } 3 \text { total } \\
\text { previous regimens of systemic therapy; } \\
\text { disease progression during or after the last } \\
\text { treatment regimen and within } 6 \text { months } \\
\text { before study enrollment; aged }>18 \text {; } \\
\text { Karnofsky PS }>70 \text {. }\end{array}$ & $\begin{array}{l}\text { Metastasis to CNS; previous treatment with } \\
\text { an mTOR inhibitor; in condition requiring } \\
\text { treatment with glucocorticoids. }\end{array}$ & $\begin{array}{l}\text { One or two previous } \\
\text { regimens of antian- } \\
\text { giogenic therapy }\end{array}$ & $\begin{array}{l}\text { Nivolumab }(3 \mathrm{mg} / \\
\mathrm{kg} \text { every } 2 \text { weeks) or } \\
\text { everolimus }(10 \mathrm{mg} / \text { day })\end{array}$ & $796(410 / 386)$ \\
\hline CheckMate $057^{811}$ & $\begin{array}{l}\text { Previously treated stage IIIB or IV } \\
\text { non-squamous NSCLC; had disease } \\
\text { recurrence or progression during or after } \\
\text { chemotherapy regimen; aged }>18 \text {; ECOG } \\
\text { PS }=0 \text { or } 1 \text {; had adequate hematologic, } \\
\text { hepatic and renal function. }\end{array}$ & $\begin{array}{l}\text { Autoimmune disease, symptomatic } \\
\text { interstitial lung disease; systemic } \\
\text { immunosuppression; prior therapy with } \\
\text { immune-stimulatory anti-tumour agents; } \\
\text { prior docetaxel therapy. }\end{array}$ & $\begin{array}{l}\text { At least one } \\
\text { platinum-based } \\
\text { doublet } \\
\text { chemotherapy }\end{array}$ & $\begin{array}{l}\text { Nivolumab }(3 \mathrm{mg} / \\
\mathrm{kg} \text { every } 2 \text { weeks) or } \\
\text { docetaxel }\left(75 \mathrm{mg} / \mathrm{m}^{2}\right. \\
\text { every } 3 \text { weeks })\end{array}$ & $582(292 / 290)$ \\
\hline CheckMate $141^{12}$ & $\begin{array}{l}\text { Recurrent squamous-cell carcinoma of the } \\
\text { head and neck of the oral cavity, pharynx } \\
\text { or larynx that was not amenable to curative } \\
\text { treatment; tumour progression or recur- } \\
\text { rence within } 6 \text { months after chemotherapy } \\
\text { or in the context of primary or recurrent } \\
\text { disease; aged }>18 \text {; ECOG PS }=0 \text { or } 1 \text {; } \\
\text { adequate bone marrow, hepatic and renal } \\
\text { function. }\end{array}$ & $\begin{array}{l}\text { Active brain metastases; autoimmune } \\
\text { disease; systemic immunosuppression; } \\
\text { known human immune-deficiency virus or } \\
\text { hepatitis B or C virus infection; previous } \\
\text { therapy targeting T cell co-stimulating or } \\
\text { immune checkpoint pathways. }\end{array}$ & $\begin{array}{l}\text { At least one } \\
\text { platinum-based } \\
\text { chemotherapy }\end{array}$ & $\begin{array}{l}\text { Nivolumab }(3 \mathrm{mg} / \mathrm{kg}) \\
\text { every } 2 \text { weeks or } \\
\text { methotrexate } \\
\left(40-60 \mathrm{mg} / \mathrm{m}^{2}\right) \text {, docetaxel } \\
\left(30-40 \mathrm{mg} / \mathrm{m}^{2}\right) \text {, or } \\
\text { cetuximab }\left(250 \mathrm{mg} / \mathrm{m}^{2}\right) \\
\text { weekly }\end{array}$ & $361(240 / 121)$ \\
\hline KEYNOTE-006 ${ }^{13}$ & $\begin{array}{l}\text { Unresectable stage III or IV melanoma; at } \\
\text { least one measurable lesion per RECIST } \\
\text { V1.1; aged }>18 \text {; ECOG PS=0 or } 1 \text {; known } \\
\text { BRAF status. }\end{array}$ & $\begin{array}{l}\text { Active brain metastases; active } \\
\text { autoimmune disease requiring systemic } \\
\text { steroids. }\end{array}$ & $\begin{array}{l}\text { Up to one previous } \\
\text { systemic therapy }\end{array}$ & $\begin{array}{l}\text { Pembrolizumab (10 mg/ } \\
\mathrm{kg} \text { every } 2 \text { or } 3 \text { weeks) or } \\
\text { ipilimumab ( } 4 \text { doses of } \\
3 \mathrm{mg} / \mathrm{kg} \text { every } 3 \text { weeks) }\end{array}$ & $834(556 / 278)$ \\
\hline KEYNOTE-045 ${ }^{14}$ & $\begin{array}{l}\text { Previously treated urothelial carcinoma of } \\
\text { the renal pelvis, ureter, bladder or urethra; } \\
\text { had progression after chemotherapy or } \\
\text { recurrence within } 12 \text { months after therapy } \\
\text { for localised muscle-invasive disease; had } \\
\text { at least one measurable lesion assessed } \\
\text { per RECIST v1.1, ECOG PS=0, } 1 \text { or } 2 \text {. }\end{array}$ & $\begin{array}{l}\text { ECOG PS=2 and had one or more of the } \\
\text { established poor prognostic factors for } \\
\text { second-line therapy. }\end{array}$ & $\begin{array}{l}\text { Two or fewer lines } \\
\text { of systemic } \\
\text { chemotherapy }\end{array}$ & $\begin{array}{l}\text { Pembrolizumab }(200 \mathrm{mg}) \\
\text { or investigator's choice of } \\
\text { paclitaxel }\left(175 \mathrm{mg} / \mathrm{m}^{2}\right) \text {, } \\
\text { docetaxel }\left(75 \mathrm{mg} / \mathrm{m}^{2}\right) \text {, or } \\
\text { vinflunine }\left(320 \mathrm{mg} / \mathrm{m}^{2}\right) \\
\text { every } 3 \text { weeks }\end{array}$ & $542(270 / 272)$ \\
\hline OAK $^{15}$ & $\begin{array}{l}\text { Previously treated NSCLC, measurable } \\
\text { disease per PECIST } \vee 1.1, \text { ECOG PS=0 or } 1 .\end{array}$ & $\begin{array}{l}\text { With a history of autoimmune disease; } \\
\text { had received previous treatment with } \\
\text { docetaxel, CD137 agonists, anti-CTLA4, or } \\
\text { therapies targeting PD-L1/PD-1 pathway. }\end{array}$ & $\begin{array}{l}1-2 \text { cytotoxic } \\
\text { chemotherapy regi- } \\
\text { mens ( } \geq 1 \text { platinum } \\
\text { based combination } \\
\text { therapy) }\end{array}$ & $\begin{array}{l}\text { Atezolizumab }(1200 \mathrm{mg}) \\
\text { or docetaxel }\left(75 \mathrm{mg} / \mathrm{m}^{2}\right) \\
\text { every } 3 \text { weeks }\end{array}$ & $850(425 / 425)$ \\
\hline POPLAR $^{16}$ & $\begin{array}{l}\text { Previously treated NSCLC; aged }>18 \text {, } \\
\text { ECOG PS=0 or 1; measurable disease by } \\
\text { RECIST v1.1; adequate hematological and } \\
\text { end-organ function. }\end{array}$ & $\begin{array}{l}\text { Active or untreated CNS metastases, } \\
\text { history of pneumonitis; autoimmune or } \\
\text { chronic viral disease; previous treated by } \\
\text { docetaxel, CD137 agonists, anti-CTLA4, } \\
\text { therapies targeting PD-L1/PD-1 pathway. }\end{array}$ & $\begin{array}{l}\text { At least one previous } \\
\text { systemic therapy }\end{array}$ & $\begin{array}{l}\text { Atezolizumab }(1200 \mathrm{mg}) \\
\text { or docetaxel }\left(75 \mathrm{mg} / \mathrm{m}^{2}\right) \\
\text { every } 3 \text { weeks }\end{array}$ & $287(144 / 143)$ \\
\hline
\end{tabular}

*Expressed as total number of patients (number of patients in intervention arm/number of patients in control arm).

NSCLC=non-small-cell lung cancer; ECOG=Eastern Cooperative Oncology Group; PS=performance status; CNS=central nervous system; RECIST=response evaluation criteria in solid tumours;

CTLA4=cytotoxic T-lymphocyte-associated protein 4. 
incomplete outcome data; and selective reporting. Two authors independently carried out the data extraction and quality assessment. Any disagreements were resolved by discussion and consensus.

\section{Statistical analysis}

The primary endpoint was the overall survival in patients that were PD-L1 positive and PD-L1 negative, measured by hazard ratios. Accordingly, we derived the hazard ratios for death and their 95\% confidence intervals from each study, separately for patients that were PD-L1 positive and PD-L1 negative. We assessed statistical heterogeneity between different trials and subgroups with the Cochrane's Q statistic. We calculated the $\mathrm{I}^{2}$ to assess the extent of inconsistency contributable to the heterogeneity across the different studies. $^{22}$ The assumption of homogeneity was considered invalid for $\mathrm{I}^{2}>25 \%$ and $\mathrm{P}<0.10$. In the present study, the pooled hazard ratios of death were calculated using the fixed effects models because no significant heterogeneities were observed in all the conducted analysis. The heterogeneity of efficacy between patients that were PD-L1 positive and PDL1 negative was assessed by an interaction test and expressed as P for interaction. Subgroup analysis was conducted to explore the variation of the effect of PDL1 expression on the immunotherapy efficacy. The selected subgroups were interventional agent, cancer type, randomisation stratified by PD-L1 expression, type of immunohistochemical scoring method, target of the interventional agent, type of control group, and median follow-up time.

Potential publication bias was assessed by visual inspection of a funnel plot, and also evaluated using the Egger and Begg tests. ${ }^{23} 24$ All analysis was carried out using Stata version 12.0 (StataCorp, College Station, TX). Two sided $\mathrm{P}<0.05$ was considered statistically significant.

Studies identified in search $(\mathrm{n}=6461)$ : PubMed $(n=2865) \quad$ Embase $(n=3169) \quad$ Cochrane $(n=427)$

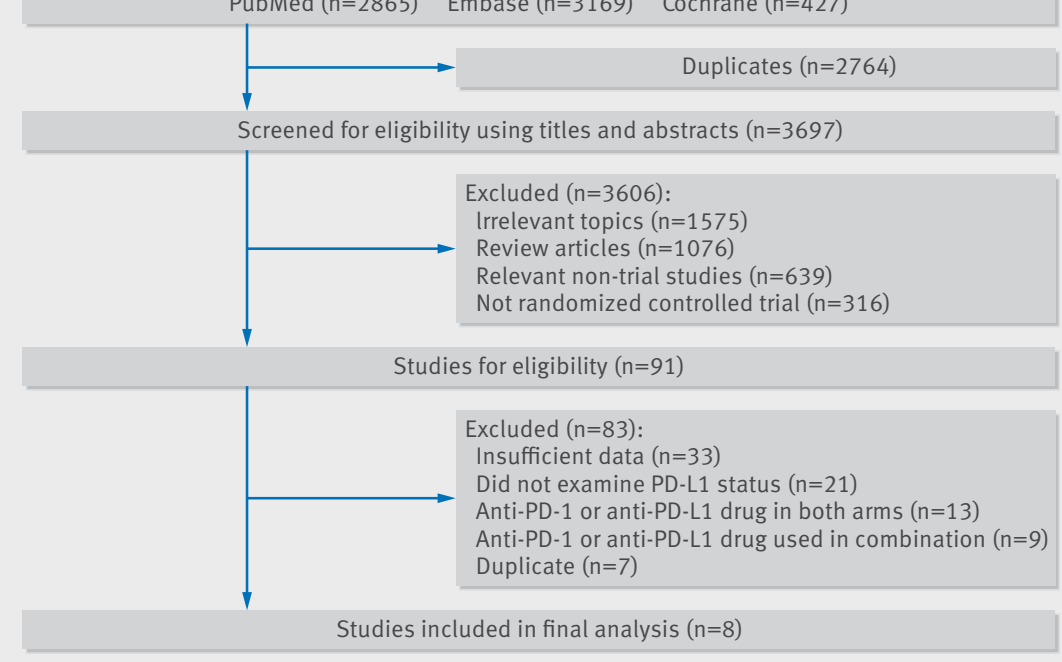

Duplicates $(n=2764)$

Fig 1 | Flowchart diagram of selected randomised controlled trials included in this metaanalysis

\section{Patient involvement}

No patients were involved in setting the research question or the outcome measures, nor were they involved in developing plans for design or implementation of the study. No patients were asked to advise on interpretation or writing up of results. There are no plans to disseminate the results of the research to study participants or the relevant patient community. It was not evaluated whether the studies included in this review had any patient involvement.

\section{Results}

\section{Literature search}

A total of 6461 related articles were identified by the initial search strategy. We removed 2764 studies because of duplications. After eligibility screening of the titles and abstracts, 3606 studies were excluded since they did not meet the inclusion criteria. We then carefully reviewed the full texts of the remaining 91 potentially eligible papers and chose eight randomised controlled trials for the final analysis. ${ }^{9-16}$ Figure 1 shows the study selection flowchart. Data from all eligible studies were obtained from published manuscripts.

\section{Study characteristics}

A total of 4174 subjects from eight randomised controlled trials were included in this study. Of all the patients included, 2254 (54\%) were PD-L1 positive, the other 1920 patients (46\%) were PD-L1 negative. Table 1 shows the main characteristics of the eligible trials. All these studies were international, multicentre, randomised controlled trials funded by the pharmaceutical industry and published between 2015 and 2017. The number of patients recruited in these eligible trials ranged from 123 to 842 . Conventional immunohistochemical test methods were used to examine the expressions of PD-L1 in all eight trials. The immunohistochemistry assay developers and antibody clones used in each study are shown in table 1.

Seven eligible studies were phase III studies, POPLAR was a phase II trial. ${ }^{16}$ The phase III randomised controlled trials included in the study, as well as other trials, provided the fundamental evidence for the United States Food and Drug Administration to license these drugs. Four studies were conducted in patients with lung cancer, ${ }^{911} 1516$ and one each in renal cancer, ${ }^{10}$ head and neck cancer, ${ }^{12}$ melanoma, ${ }^{13}$ and urothelial cancer. ${ }^{14}$ All studies were performed in advanced or metastatic settings, and 1809 (43\%) of 4174 patients had advanced or metastatic non-smallcell lung cancer. No randomised controlled trials using PD-1 or PD-L1 inhibitors in patients with early-stage cancer reported overall survival data based on PD-L1 expression status. Subjects in the intervention arm received nivolumab in four studies, ${ }^{9-12}$ pembrolizumab in two studies, ${ }^{1314}$ and atezolizumab in two studies. ${ }^{15} 16$ PD-1 or PD-L1 blockade immunotherapy was used as second line or later treatment for most patients, and as first line treatment for some patients in the KEYNOTE-006 study. ${ }^{13}$ 
Overall survival was the primary endpoint for all the eligible trials. Randomised treatment allocation sequences were generated in all studies. Randomisation stratified by PD-L1 expression was conducted in the KEYNOTE-006, ${ }^{13}$ OAK, ${ }^{15}$ and POPLAR studies. ${ }^{16}$ The method quality of the included trials was generally moderate to good (see supplementary materials, supplementary table 1). The main issue affecting quality was lack of blinding because all trials were open labelled.

\section{Efficacy of PD-1 or PD-L1 inhibitors and PD-L1 expression status}

Overall, patients that were PD-L1 positive and were treated with PD-1 or PD-L1 inhibitors as monotherapy had a significantly reduced risk of death compared with patients in the control groups (hazard ratio 0.66, $95 \%$ confidence interval 0.59 to $0.74, \mathrm{P}<0.001$ ) (see fig 2). No substantial heterogeneity was observed among single-study estimates in patients that were PD-L1 positive $\left(\mathrm{Q}=3.7, \mathrm{P}=0.81, \mathrm{I}^{2}=0.0 \%\right)$. Patients that were PD-L1 negative and were treated with PD-1 or PD-L1 inhibitors were also associated with a better overall survival compared with controls (hazard ratio $0.80,95 \%$ confidence interval 0.71 to $0.90, \mathrm{P}<0.001$ ) (see fig 2). Similarly, no substantial heterogeneity was observed among single-study estimates in patients that were PD-L1 negative $\left(\mathrm{Q}=5.5, \mathrm{P}=0.61, \mathrm{I}^{2}=0.0 \%\right)$. The pooled estimate of the hazard ratio including both patients that were PD-L1 positive and PD-L1 negative was 0.72 (95\% confidence interval 0.67 to $0.78, \mathrm{P}<0.001)$. It should be noted that there was a

\begin{tabular}{|c|c|c|c|c|c|}
\hline \multirow[b]{2}{*}{ Study } & \multicolumn{2}{|c|}{ No of patients } & \multirow[b]{2}{*}{$\begin{array}{c}\text { Overall survival } \\
\text { hazard ratio } \\
(95 \% \mathrm{Cl})\end{array}$} & \multirow[b]{2}{*}{$\begin{array}{c}\text { Weight } \\
\text { (\%) }\end{array}$} & \multirow[b]{2}{*}{$\begin{array}{l}\text { Overall survival } \\
\text { hazard ratio } \\
(95 \% \mathrm{Cl})\end{array}$} \\
\hline & ntervention & $\overline{\text { Control }}$ & & & \\
\hline CheckMate 017 & 63 & 56 & & 7.82 & $0.75(0.50$ to 1.10$)$ \\
\hline CheckMate 025 & 94 & 87 & & 7.75 & $0.79(0.53$ to 1.17$)$ \\
\hline CheckMate 057 & 123 & 123 & & 15.02 & $0.62(0.47$ to 0.83$)$ \\
\hline CheckMate 141 & 88 & 61 & & 6.96 & 0.55 (0.36 to 0.83$)$ \\
\hline KEYNOTE-006 & 446 & 225 & & 21.99 & $0.63(0.50$ to 0.80$)$ \\
\hline KEYNOTE-045 & NR & NR & & 10.11 & 0.61 (0.43 to 0.86$)$ \\
\hline OAK & 241 & 222 & & 21.79 & $0.74(0.58$ to 0.93$)$ \\
\hline POPLAR & 93 & 102 & & 8.55 & $0.59(0.40$ to 0.85$)$ \\
\hline \multicolumn{3}{|c|}{ Overall: $P=0.81, I^{2}=0 \%$} & & 100.00 & $0.66(0.59$ to 0.74$)$ \\
\hline \multicolumn{6}{|l|}{ PD-L1 negative } \\
\hline CheckMate 017 & 54 & 52 & & 7.99 & $0.57(0.38$ to 0.86$)$ \\
\hline CheckMate 025 & 276 & 299 & & 23.09 & 0.77 (0.60 to 0.97$)$ \\
\hline CheckMate 057 & 108 & 101 & & 14.83 & 0.91 (0.67 to 1.22$)$ \\
\hline CheckMate 141 & 73 & 38 & & 5.46 & $0.89(0.54$ to 1.45$)$ \\
\hline KEYNOTE-006 & 103 & 47 & & 6.29 & 0.75 (0.47 to 1.19$)$ \\
\hline KEYNOTE-045 & NR & NR & & 14.91 & 0.89 (0.66 to 1.20$)$ \\
\hline OAK & 180 & 199 & & 22.48 & $0.75(0.59$ to 0.96$)$ \\
\hline POPLAR & 51 & 41 & & 4.95 & $1.04(0.62$ to 1.75$)$ \\
\hline \multicolumn{3}{|c|}{ Overall: $P=0.61, I^{2}=0 \%$} & & 100.00 & $0.80(0.71$ to 0.90$)$ \\
\hline \multicolumn{3}{|r|}{0.5} & 1 & \multicolumn{2}{|l|}{1.5} \\
\hline
\end{tabular}

Fig 2 | Hazard ratio of death for patients that are PD-L1 positive and PD-L1 negative assigned to intervention treatment, compared with those in control group. The therapy effects are calculated with fixed effects models. $N R=$ not reported significant difference in the efficacy of PD-1 or PD-L1 inhibitors between patients that were PD-L1 positive and PD-L1 negative, when compared with controls ( $\mathrm{P}=0.02$ for interaction).

Figure 3 and figure 4 show the results of subgroup analyses. For subgroups including cancer histotype, method of randomised stratification, type of immunohistochemical scoring method, target of intervention agents, type of control group, and median follow-up duration, both patients that were PD-L1 positive and PD-L1 negative could benefit from PD-1 or PD-L1 blockade therapy. Partly owing to the limited number of patients involved, our data showed that the survival benefit from pembrolizumab treatment in patients that were PD-L1 negative was marginal. In all the selected subgroups, the magnitude of efficacy of PD-1 or PD-L1 inhibitors was greater for patients that were PD-L1 positive than for patients that were PD-L1 negative.

\section{Publication bias}

Visual inspection of the Begg funnel plot did not identify substantial asymmetry (supplementary materials, supplementary fig 1). The Begg rank correlation test and Egger linear regression test also indicated no evidence of publication bias.

\section{Discussion}

This study is the first meta-analysis focused on the association between PD-1 or PD-L1 inhibitors and long-term outcomes in patients with cancer that are PD-L1 positive and PD-L1 negative. With published data from eight high quality randomised controlled trials, for more than 4000 patients with five types of advanced solid tumours, our pooled analysis revealed that, compared with conventional therapy, PD-1 or PDL1 blockade treatment decreased the risk of death by $34 \%$ in patients that were PD-L1 positive and by $20 \%$ in patients that were PD-L1 negative. Furthermore, these survival benefits were consistent across the selected subgroup analysis. Therefore, our study suggests that PD-1 or PD-L1 inhibitor therapy is a preferable to conventional therapy for treating patients that are PD-L1 positive and PD-L1 negative. Moreover, PD-L1 expression alone was not an adequate biomarker in patient selection for routine clinical practice in PD-1 or PD-L1 blockade therapy.

\section{Comparison with other studies}

Most of the previous studies examined the role of PD-L1 expression as a predictive biomarker rather than as a prognostic biomarker, ${ }^{7} 17$ partly because only limited information regarding overall survival in patients that are PD-L1 negative is available. Even as a predictive biomarker for tumour responses, the role of PD-L1 remained controversial due to the existence of various antibody clones, positivity or negativity cut-offs, and sometimes the scoring system. It was revealed that clone SP142 bound to the cytoplasmic domain of PD-L1, while the clones 22C3, 28-8, and 
SP263 bound to the extracellular domain of PDL1. ${ }^{25}$ Consequently, the positive rate using SP142 was lower than those obtained using clones 22C3, 28-8, and SP263 according to the Blueprint Working Group. $^{26}$ Additionally, in pembrolizumab trials, extensive biomarker research had been conducted in the KEYNOTE-001 study resulting in the identification of positivity for PD-L1 expression as $50 \%{ }^{27}$ Moreover, $1 \%, 5 \%$, and $10 \%$ were often applied as the cut-off values for the definition of PD-L1 positivity. In this study, to minimise these technique issues, only high quality multicentred randomised controlled trials were eligible for analysis. Furthermore, a very strict cut-off value $(<1 \%)$ was set in the definition of PD-L1 negativity. This threshold meant that the expression of PD-L1 was almost undetectable in tumour samples.

One of the most important unanswered questions in immunotherapy is whether PD-L1 is a prognostic biomarker for overall survival, which is the gold standard for therapeutic intervention in cancer. ${ }^{28}$ Several previous studies revealed that favourable longterm outcomes can be achieved in patients that are PDL1 negative. ${ }^{81018}$ However, because it was generally believed that the negative expression of PD-L1 was associated with weak or no pre-existing anticancer immunity, some clinicians and scientists tended to explain it by technical arguments including: limited PD-L1 negative tissues available; the expression of PD-L1 was evaluated in archival tissues, which might not reflect the PD-L1 status at the time of treatment; PD-L1 expression in tumours was not uniform, and sampling location may affect the results of PDL1 staining; and different molecular mechanisms might involve PD-L1 expression in different tumour histology. In this study, a strength of our analysis is the quality of evidence available for use. Most data were obtained from phase III randomised controlled trials, and results are based on the well-defined endpoint of overall survival of about 2000 patients that were PD-L1 negative. Considering a relatively low number of patients that were PD-L1 negative were enrolled in each trial, the large number of patients is a crucial point to overcome the problem of inadequate power of individual trials, and to attenuate the potential impact of the dynamic expression of PD-L1. Our results revealed that PD-1 or PD-L1 inhibitors were associated with prolonged overall survival in patients that were PD-L1 negative. Furthermore, the relevance of our findings is strengthened by their consistency across all analysed subsets. The heterogeneities within

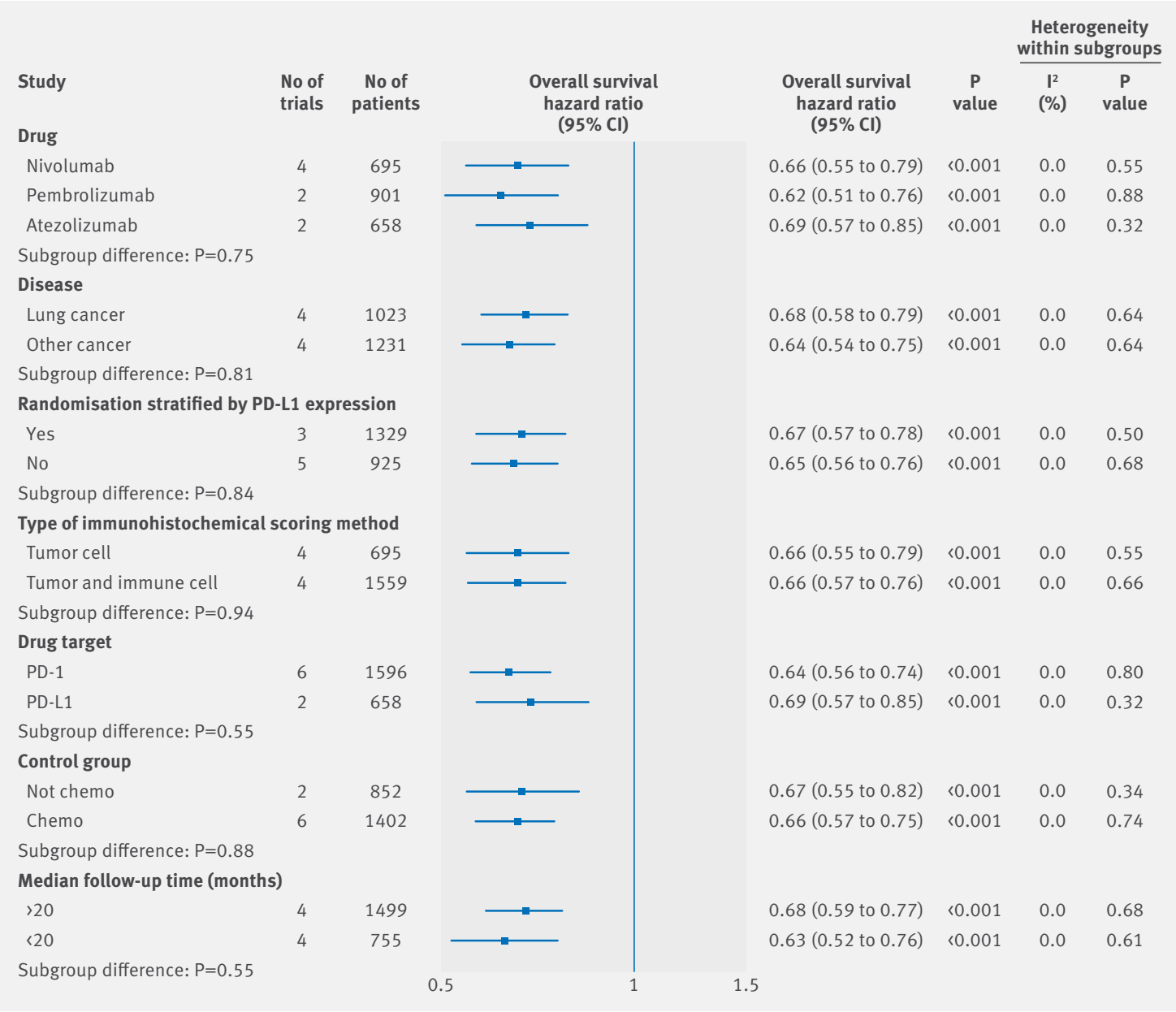

Fig 3 | Subgroup analyses for overall survival in patients that are PD-L1 positive assigned to intervention treatment, compared with those assigned to control treatment 
each subgroup were not significant and supported our conclusions, although it cannot be excluded that insufficient statistical power might account for these results. In summary, we believe the favourable overall survival achieved in patients that were PD-L1 negative is because of the biological function of the PD- 1 or PD-L1 pathway itself and the complicated interaction between cancer cells and the immune system.

\section{Possible explanations}

It is well established that the interaction between cancer and immunity is a dynamic process, different steps in this process by which tumour escape immune-surveillance are likely to be different for each patient. $^{3}$ 29-31 Currently, the molecular association between PD-L1 expression and anti-tumour immunity is not fully understood. ${ }^{2}$ Accumulating evidence has revealed that the expression of PD-L1 was regulated at transcriptional, post-transcriptional, and protein levels. ${ }^{23}$ In clinical practice, conventional treatments such as chemotherapy and radiotherapy are also considered as potential regulators of PD-L1 expression as well as the anti-tumour immunity. ${ }^{28}$ A recent study suggested that the PD-L1 inhibitor itself can increase the anti-tumour immunity though enhanced priming of new anticancer immune responses. ${ }^{15}$ It was proposed that PD-L1 blockade reactivated rare tumour-reactive T cells, the resulting local cytokine secretion induced multiple positive feedback loops: the production of CXC chemokinescould promote $\mathrm{T}$ cell infiltration, ${ }^{2} 32$ and the increased expression of components of the antigen presentation machinery could enhance visibility to tumour cells to T cells. ${ }^{32}$ Accordingly, it seems more important to understand whether the PD-1 or PD-L1 pathway is active in the tumour rather than solely focusing on the expression of PD-L1. It is noted that a clearly positive benefit of immunotherapy in patients that were PD-L1 negative was obtained from three trials: CheckMate 017 (squamous-cell non-smallcell lung cancer), CheckMate 025 (kidney cancer), and OAK (non-small-cell lung cancer). These cancers are associated with higher mutational load (nonsynonymous single nucleotide variants or frequency of indel) and higher neoantigen load, ${ }^{33} 34$ which potentially result in a higher likelihood of chance of response to PD-1 or PD-L1 inhibitors. In addition, PD-1 interacts with two ligands, PD-L1 and PD-L2. Although PD-L1 is the dominant ligand for PD-1, PDL2 can compete with PD-L1 with two to sixfold higher affinity to PD-1 than PD-L1. ${ }^{35}$ Unfortunately, the role of

\begin{tabular}{|c|c|c|c|c|c|c|c|}
\hline \multirow[b]{2}{*}{ Study } & \multirow[b]{2}{*}{$\begin{array}{l}\text { No of } \\
\text { trials }\end{array}$} & \multirow[b]{2}{*}{$\begin{array}{c}\text { No of } \\
\text { patients }\end{array}$} & \multirow[b]{2}{*}{$\begin{array}{l}\text { Overall survival } \\
\text { hazard ratio } \\
(95 \% \mathrm{CI})\end{array}$} & \multirow[b]{2}{*}{$\begin{array}{l}\text { Overall survival } \\
\text { hazard ratio } \\
(95 \% \mathrm{Cl})\end{array}$} & \multirow[b]{2}{*}{$\begin{array}{c}P \\
\text { value }\end{array}$} & \multicolumn{2}{|c|}{$\begin{array}{c}\text { Heterogeneity } \\
\text { within subgroups }\end{array}$} \\
\hline & & & & & & $\begin{array}{l}I^{2} \\
(\%)\end{array}$ & $\begin{array}{c}P \\
\text { value }\end{array}$ \\
\hline Nivolumab & 4 & 1001 & $\longrightarrow$ & 0.78 (0.67 to 0.92$)$ & 0.003 & 15.9 & 0.31 \\
\hline Pembrolizumab & 2 & 448 & 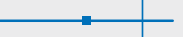 & 0.85 (0.66 to 1.09$)$ & 0.194 & 0.0 & 0.54 \\
\hline \multicolumn{8}{|c|}{ Subgroup difference: $\mathrm{P}=0.88$} \\
\hline \multicolumn{8}{|l|}{ Disease } \\
\hline Lung cancer & 4 & 1001 & $\rightarrow$ & 0.79 (0.67 to 0.92$)$ & 0.004 & 34.2 & 0.21 \\
\hline Other cancer & 4 & 919 & 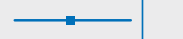 & $0.81(0.69$ to 0.96$)$ & 0.014 & 0.0 & 0.85 \\
\hline \multicolumn{8}{|c|}{ Subgroup difference: $\mathrm{P}=0.76$} \\
\hline \multicolumn{8}{|c|}{ Subgroup difference: $\mathrm{P}=0.85$} \\
\hline \multicolumn{8}{|c|}{ Type of immunohistochemical scoring method } \\
\hline Tumor cell & 4 & 1001 & $\longrightarrow$ & 0.78 (0.67 to 0.92$)$ & 0.003 & 15.9 & 0.31 \\
\hline Tumor and immune cell & 4 & 919 & $\longrightarrow$ & 0.82 (0.69 to 0.96$)$ & 0.017 & 0.0 & 0.63 \\
\hline \multicolumn{8}{|c|}{ Subgroup difference: $\mathrm{P}=0.72$} \\
\hline \multicolumn{8}{|l|}{ Drug target } \\
\hline PD-1 & 6 & 1449 & 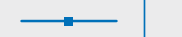 & $0.80(0.70$ to 0.92$)$ & 0.001 & 0.0 & 0.52 \\
\hline PD-L1 & 2 & 471 & & 0.80 (0.64 to 0.99$)$ & 0.042 & 20.0 & 0.26 \\
\hline \multicolumn{8}{|c|}{ Subgroup difference: $P=0.96$} \\
\hline Subgroup difference: $\mathrm{P}=$ & & 0.5 & 1 & & & & \\
\hline
\end{tabular}

Fig 4 | Subgroup analyses for overall survival in patients that are PD-L1 negative assigned to intervention treatment, compared with those assigned to control treatment 
PD-L2 as a predictive or prognostic marker has not been evaluated. Given the heterogeneity in clinical response to PD-1 or PD-L1 inhibitors, a conceptual point of view summarised as "cancer immunogram" was introduced. ${ }^{32}$ In this model, the outcome of PD-1 or PDL1 blockade therapy was influenced not only by PD-L1 expression, but also by many unrelated characteristics including: the "foreignness" of the cancer; the immune status; the activity of the intra-tumoral T cell infiltrate; the presence of other inhibitory processes; and the sensitivity of cancer cells to T cells.

\section{Implications of findings}

Our results have several clinical and research implications. Firstly, PD-1 or PD-L1 blockade therapy is a preferable treatment option even for patients that are PD-L1 negative. PD-1 or PD-L1 blockade immunotherapy has replaced conventional chemotherapy as the new standard second or later line treatment in many cancers in the past several years. ${ }^{36-39}$ Our results may potentially lead to an increasing administration of PD-1 or PD-L1 inhibitors in patients that are PD-L1 negative. Furthermore, considering that immunotherapy has an estimated cost of more than $€ 234000$ ( $€ 258000 ; \$ 300000$ ) per quality adjusted life year, ${ }^{6}$ the economic consequences are tremendous for patients, their families, and society. Secondly, it is known that multiple distinct diagnostic assays are needed for determining the expression of PD-L1 to guide therapy with different inhibitors, it creates a barrier for routine implementation of PD-L1 testing in the real world because of the impracticality of performing repeated examination of the same protein. Since our results here revealed that both patients that are PD-L1 positive and PD-L1 negative can benefit from PD-1 or PD-L1 inhibitors, the role of PD-L1 testing declines in clinical practice. Thirdly, in PD-1 or PD-L1 blockade immunotherapy, PD-L1 expression alone was not an adequate biomarker in patient selection for routine clinical practice. Future research should focus on improving the activity of PD-1 or PD-L1 pathway rather than PD-L1 expression. Moreover, treatment selection should consider the patient's clinical and pathological characteristics, treatment histories, and preferences.

\section{Weaknesses of this study}

This study also has some limitations. Firstly, an optimal treatment strategy needed to maximise the benefit as well as minimise the risk of toxicities. Toxicity profile is another important factor in choosing therapy options. However, it was impossible to conduct such an analysis to deal with this issue here because all the information regarding adverse events from the included patients that were PD-L1 negative were unavailable. Secondly, although all the eligible studies conducted the randomisation process adequately, randomisations were stratified by PD-L1 expression in some trials, ${ }^{13} 1516$ an imbalance of patient characteristics between two treatment groups can still exist. However, it should be noted that there is no significant difference in terms of overall survival between studies in which patients are randomised according to $\mathrm{PD}-\mathrm{L} 1$ expression and trials in which patients are not (see fig 3 and fig 4). Thirdly, we carried out the present study at the trial level, no clinicopathological characteristics at individual level were examined. This might reduce our ability to test for associations between variables in specific subgroups. Fourthly, it should be noted that some subgroup analysis conducted in this study included only a few trials. It cannot be excluded that insufficient statistical power might account for the results obtained from these subgroup analyses. Accordingly, these results should be interpreted with caution. Fifthly, we examined subgroups of patients (ie, patients that were PD-L1 positive and PD-L1 negative) in the eligible eight randomised controlled trials. Although most studies provided a balance between intervention arms, subgroup analysis, by its nature, might introduce bias to our analysis.

Despite these limitations, this study is the largest meta-analysis that incorporates results from eight randomised controlled trials with over 4000 patients with cancer.

\section{Conclusions}

PD-1 or PD-L1 inhibitors, compared with conventional agents, prolonged overall survival in both patients with advanced solid tumour that were PD-L1 positive and PD-L1 negative as second and later lines of treatment. We cannot recommend PD-L1 expression status as prognostic biomarker in patients' selection in PD-1 or PD-L1 blockade therapy. The finding of this meta-analysis could also assist in biomarker and drug development, economic analyses, and future clinical trial designs.

Contributors: XS and BZ conceived the study, acquired the data, analysed the data, and wrote the manuscript. BZ is the guarantor. Funding: None.

Competing interests: All authors have completed the ICMJE form disclosure form at www.icmje.org/coi_disclosure.pdf and declare: no support from any organisation for the submitted work; no financial relationships with any organisations that might have an interest in the submitted work in the previous three years; no other relationships or activities that could appear to have influenced the submitted work.

\section{Ethical approval: Not required.}

Data sharing: No additional data are available.

Transparency: The manuscripts guarantor (BZ) affirms that the manuscript is an honest, accurate, and transparent account of the study being reported; that no important aspects of the study have been omitted; and that any discrepancies from the study as planned have been explained.

This is an Open Access article distributed in accordance with the Creative Commons Attribution Non Commercial (CC BY-NC 4.0) license, which permits others to distribute, remix, adapt, build upon this work non-commercially, and license their derivative works on different terms, provided the original work is properly cited and the use is noncommercial. See: http://creativecommons.org/licenses/by-nc/4.0/.

1 Hanahan D, Weinberg RA. Hallmarks of cancer: the next generation. Cell 2011;144:646-74. doi:10.1016/j.cell.2011.02.013

2 Sun C, Mezzadra R, Schumacher TN. Regulation and Function of the PD-L1 Checkpoint. Immunity 2018;48:434-52. doi:10.1016/j. immuni.2018.03.014

3 Ribas A, Wolchok JD. Cancer immunotherapy using checkpoint blockade. Science 2018;359:1350-5. doi:10.1126/science. aar4060

4 Xu-Monette ZY, Zhang M, Li J, Young KH. PD-1/PD-L1 Blockade: Have We Found the Key to Unleash the Antitumor Immune Response? Front Immunol 2017;8:1597. doi:10.3389/fimmu.2017.01597 
5 Baxi S, Yang A, Gennarelli RL, et al. Immune-related adverse events for anti-PD-1 and anti-PD-L1 drugs: systematic review and metaanalysis. BMJ 2018;360:k793. doi:10.1136/bmj.k793

6 Wang J, Chmielowski B, Pellissier J, Xu R, Stevinson K, Liu FX. Cost-Effectiveness of Pembrolizumab Versus Ipilimumab in Ipilimumab-Naïve Patients with Advanced Melanoma in the United States. J Manag Care Spec Pharm 2017;23:184-94. doi:10.18553/jmcp.2017.23.2.184

7 Gibney GT, Weiner LM, Atkins MB. Predictive biomarkers for checkpoint inhibitor-based immunotherapy. Lancet Oncol 2016;17:e542-51. doi:10.1016/S1470-2045(16)30406-5

8 Horn L, Spigel DR, Vokes EE, et al. Nivolumab Versus Docetaxel in Previously Treated Patients With Advanced Non-Small-Cell Lung Cancer: Two-Year Outcomes From Two Randomized, Open-Label, Phase III Trials (CheckMate 017 and CheckMate 057). J Clin Oncol 2017:35:3924-33. doi:10.1200//CO.2017.74.3062

9 Brahmer J, Reckamp KL, Baas P, et al. Nivolumab versus Docetaxel in Advanced Squamous-Cell Non-Small-Cell Lung Cancer. N EnglJ Med 2015:373:123-35. doi:10.1056/NEIMoa1504627

10 Motzer RJ, Escudier B, McDermott DF, et al, CheckMate 025 Investigators. Nivolumab versus Everolimus in Advanced Renal-Cell Carcinoma. N Engl J Med 2015;373:1803-13. doi:10.1056/NEJMoa1510665

11 Borghaei H, Paz-Ares L, Horn L, et al. Nivolumab versus Docetaxel in Advanced Nonsquamous Non-Small-Cell Lung Cancer. N EnglJ Med 2015:373:1627-39. doi:10.1056/NEJMoa1507643

12 Ferris RL, Blumenschein G Jr, Fayette J, et al. Nivolumab for Recurrent Squamous-Cell Carcinoma of the Head and Neck. N Engl J Med 2016:375:1856-67. doi:10.1056/NEIMoa1602252

13 Schachter J, Ribas A, Long GV, et al. Pembrolizumab versus ipilimumab for advanced melanoma: final overall survival results of a multicentre, randomised, open-label phase 3 study (KEYNOTE-006). Lancet 2017;390:1853-62. doi:10.1016/S0140-6736(17)31601-X

14 Bellmunt J, de Wit R, Vaughn DJ, et al, KEYNOTE-045 Investigators. Pembrolizumab as Second-Line Therapy for Advanced Urothelial Carcinoma. N Engl / Med 2017;376:1015-26. doi:10.1056/ NEJMoa1613683

15 Rittmeyer A, Barlesi F, Waterkamp D, et al, OAK Study Group. Atezolizumab versus docetaxel in patients with previously treated non-small-cell lung cancer (OAK): a phase 3, open-label, multicentre randomised controlled trial. Lancet 2017;389:255-65. doi:10.1016/ S0140-6736(16)32517-X

16 Fehrenbacher L, Spira A, Ballinger M, et al, POPLAR Study Group. Atezolizumab versus docetaxel for patients with previously treated non-small-cell lung cancer (POPLAR): a multicentre, open-label, phase 2 randomised controlled trial. Lancet 2016;387:1837-46. doi:10.1016/S0140-6736(16)00587-0

17 Khagi Y, Kurzrock R, Patel SP. Next generation predictive biomarkers for immune checkpoint inhibition. Cancer Metastasis $\operatorname{Rev}$ 2017;36:179-90. doi:10.1007/s10555-016-9652-y

18 Robert C, Long GV, Brady B, et al. Nivolumab in previously untreated melanoma without BRAF mutation. N Engl J Med 2015;372:320-30. doi:10.1056/NEIMoa1412082

19 Büttner R, Gosney JR, Skov BG, et al. Programmed Death-Ligand 1 Immunohistochemistry Testing: A Review of Analytical Assays and Clinical Implementation in Non-Small-Cell Lung Cancer. / Clin Oncol 2017;35:3867-76. doi:10.1200/JCO.2017.74.7642

20 Liberati A, Altman DG, Tetzlaff J, et al. The PRISMA statement for reporting systematic reviews and meta-analyses of studies that evaluate health care interventions: explanation and elaboration. PLoS Med 2009;6:e1000100. doi:10.1371/journal.pmed.1000100

21 Higgins JP, Altman DG, Gøtzsche PC, et al, Cochrane Bias Methods Group, Cochrane Statistical Methods Group. The Cochrane Collaboration's tool for assessing risk of bias in randomised trials. BMJ 2011;343:d5928. doi:10.1136/bmj.d5928

22 Higgins JP, Thompson SG, Deeks JJ, Altman DG. Measuring inconsistency in meta-analyses. BMJ 2003;327:557-60 doi:10.1136/bmj.327.7414.557
23 Egger M, Davey Smith G, Schneider M, Minder C. Bias in meta-analysis detected by a simple, graphical test. BMJ 1997:315:629-34 doi:10.1136/bmj.315.7109.629

24 Begg CB, Mazumdar M. Operating characteristics of a rank correlation test for publication bias. Biometrics 1994;50:1088-101. doi: $10.2307 / 2533446$

25 Takada K, Toyokawa G, Shoji F, Okamoto T, Maehara Y. The Significance of the PD-L1 Expression in Non-Small-Cell Lung Cancer: Trenchant Double Swords as Predictive and Prognostic Markers. Clin Lung Cancer 2018;19:120-9. doi:10.1016/j.cllc.2017.10.014

26 Hirsch FR, McElhinny A, Stanforth D, et al. PD-L1 Immunohistochemistry Assays for Lung Cancer: Results from Phase 1 of the Blueprint PD-L1 IHC Assay Comparison Project. J Thorac Oncol. 2017;12(2):208-222. doi:10.1016/j.jtho.2016.11.2228

27 Dolled-Filhart M, Roach C, Toland G, et al. Development of a Companion Diagnostic for Pembrolizumab in Non-Small Cell Lung Cancer Using Immunohistochemistry for Programmed Death Ligand-1. Arch Pathol Lab Med 2016. doi:10.5858/ arpa.2015-0542-OA

28 Melosky B, Chu Q, Juergens RA, et al. Breaking the biomarker code: PD-L1 expression and checkpoint inhibition in advanced NSCLC. Cancer Treat Rev 2018;65:65-77. doi:10.1016/j.ctrv.2018.02.005

29 Gajewski TF, Schreiber H, Fu YX. Innate and adaptive immune cells in the tumor microenvironment. Nat Immunol 2013;14:1014-22. doi:10.1038/ni.2703

30 Rooney MS, Shukla SA, Wu CJ, Getz G, Hacohen N. Molecular and genetic properties of tumors associated with local immune cytolytic activity. Cell 2015;160:48-61. doi:10.1016/j.cell.2014.12.033

31 Tumeh PC, Harview CL, Yearley JH, et al. PD-1 blockade induces responses by inhibiting adaptive immune resistance. Nature 2014;515:568-71. doi:10.1038/nature13954

32 Blank CU, Haanen JB, Ribas A, Schumacher TN. CANCER IMMUNOLOGY. The "cancer immunogram". Science 2016;352:658-60. doi:10.1126/science.aaf2834

33 Matsushita H, Sato Y, Karasaki T, et al. Neoantigen Load, Antigen Presentation Machinery, and Immune Signatures Determine Prognosis in Clear Cell Renal Cell Carcinoma. Cancer Immunol Res 2016:4:463-71. doi:10.1158/2326-6066.CIR-15-0225

34 Anagnostou V, Smith KN, Forde PM, et al. Evolution of Neoantigen Landscape during Immune Checkpoint Blockade in Non-Small Cell Lung Cancer. Cancer Discov 2017;7:264-76. doi:10.1158/2159-8290.CD-16-0828

35 Youngnak P, Kozono Y, Kozono $\mathrm{H}$, et al. Differential binding properties of B7-H1 and B7-DC to programmed death-1. Biochem Biophys Res Commun 2003;307:672-7. doi:10.1016/S0006291X(03)01257-9

36 Socinski MA, Obasaju C, Gandara D, et al. Current and Emergent Therapy Options for Advanced Squamous Cell Lung Cancer. / Thorac Oncol . 2018;13(2):165-83. doi:10.1016/j.jtho.2017.11.111

37 Yousefi H, Yuan J, Keshavarz-Fathi M, Murphy JF, Rezaei N. Immunotherapy of cancers comes of age. Expert Rev Clin Immunol 2017;13:1001-15. doi:10.1080/174466 6X.2017.1366315

38 Joseph RW, Chatta G, Vaishampayan U Nivolumab treatment for advanced renal cell carcinoma: Considerations for clinical practice. Urol Oncol 2017;35:142-8. doi:10.1016/j.urolonc.2017.01.017

39 Lee CK, Man J, Lord S, et al. Clinical and Molecular Characteristics Associated With Survival Among Patients Treated With Checkpoint Inhibitors for Advanced Non-Small Cell Lung Carcinoma: A Systematic Review and Meta-analysis. JAMA Oncol 2018;4:210-6. doi:10.1001/jamaoncol.2017.4427

Supplementary materials: Search strategies, supplementary table 1, and supplementary figure 1 